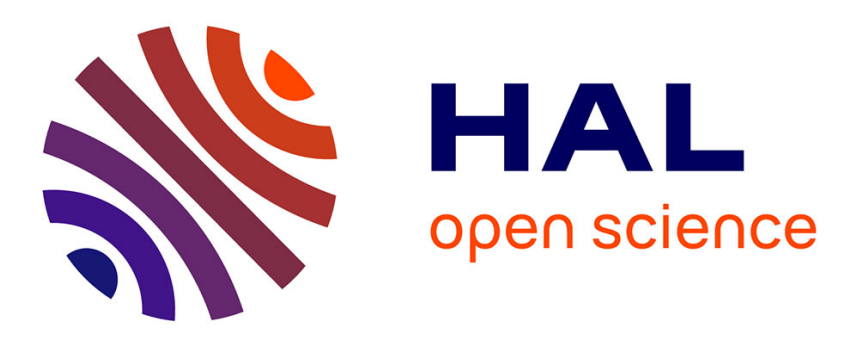

\title{
In search of an alternative to shareholder value maximization
}

Gaël Giraud, Cécile Renouard

\section{To cite this version:}

Gaël Giraud, Cécile Renouard. In search of an alternative to shareholder value maximization. 2011, pp.31. hal-00609153

\section{HAL Id: hal-00609153 \\ https://essec.hal.science/hal-00609153}

Submitted on 18 Jul 2011

HAL is a multi-disciplinary open access archive for the deposit and dissemination of scientific research documents, whether they are published or not. The documents may come from teaching and research institutions in France or abroad, or from public or private research centers.
L'archive ouverte pluridisciplinaire HAL, est destinée au dépôt et à la diffusion de documents scientifiques de niveau recherche, publiés ou non, émanant des établissements d'enseignement et de recherche français ou étrangers, des laboratoires publics ou privés. 
In Search of an alternative to Shareholder Value Maximization

\author{
Research Center \\ ESSEC Working Paper 1108 \\ July 2011
}

Gaël Giraud

Cécile Renouard 


\title{
In search of an alternative to shareholder value maximization
}

\author{
GAËL GIRAUD* \\ CNRS, Paris School of Economics, ESCP-Europe, France. \\ CÉCIle Renouard ${ }^{\dagger}$ \\ ESSEC Business School.
}

July 8, 2011

\begin{abstract}
This paper argues that mainstream economic theory, far from providing an indisputable plea in favor of shareholder value-maximization, offers striking arguments showing quite the opposite: profit-maximization cannot be a legitimate prioritarian goal for private firms. This opens the door for a widening of a company's goal. We argue that it should include the concern of all the stakeholders of a company, and cannot be adequately addressed uniquely by Pigouvian taxes or by property rights. Coming to terms with this broad understanding of a company's goal should imply the internalization of the stakeholders' concern within the legal structure of the firm - as in the case of the SCIC in France or the CIC in the UK.
\end{abstract}

Key words: Corporate social responsibility, shareholder value, stakeholder value, incomplete markets, limited liability, property rights, collateral, cooperative.

JEL classification: A12, D21, D63, K11, L21, L33, M14.

\section{Introduction}

Shareholder value maximization is widely understood as being the primary and, often, the unique goal that should be pursued by a private corporation. As a matter of fact, the aim of economic activity has been less and less a matter of debate, as Western market capitalism expanded during the 19th

*gael.giraud@parisschoolofeconomics.fr

${ }^{\dagger}$ renouard@essec.fr 
and the 20th centuries: every private firm, so it is argued, has to take part in global competition and contributes to global wealth through the taxes it pays to the government, the wages it pays to its employees and through the dividends it distributes to its investors/shareholders. The more profitable the company, the more it will contribute directly or indirectly to the common good.

It is widely assumed that neo-classical economic theory, especially its core model known as General Equilibrium Theory (GET), unanimously justifies this standpoint. In this paper, we argue that this is not true. Of course, underlying the illusion that GET could be used as a tool for justifiying the traditional understanding of a corporation's purpose is the classical first welfare theorem with convex production and complete markets, no public goods and no externalities (Arrow (1951), Debreu (1951) and Arrow \& Debreu (1954)). It suggests that, if all the households of a given economy maximize their utility under their budget constraints and all the firms maximize their profit, given their technological production constraints, then an Arrow-Debreu equilibrium exists, is locally unique and, above all, is Pareto-optimal. In section 2 of this paper, we briefly review the now classical results obtained when some of the utterly unrealistic assumptions underlying this textbook result is dropped. Our point of view is that the conclusion is unambiguous: General equilibrium theory, far from providing an indisputable plea in favor of shareholder value maximization, offers striking arguments showing quite the opposite - profit maximization cannot be considered as being a legitimate goal for private firms, neither on the grounds of efficiency nor equity.

This makes possible a widening of corporations' goals. By contrast with the traditional viewpoint that often tends to reduce corporations to cash machines for their shareholders, proponents of the "stakeholder" view of corporations assert that managers should also pay attention to the welfare of their employees and consumers. The shareholder view held by most mainstream economists is a tradition inherited from the Anglo-American understanding of corporations, while the so-called non-orthodox stakeholder view is that held in countries such as Japan and most continental European countries. The way in which a society views the role of a corporation can be traced to its legal system and to the social norms which shape the way citizens think about the role of institutions. Common Law countries such as the UK and the US view a corporation as a piece of private property and through their legal structure place exclusive emphasis on the shareholders as the owners of the firm. Roman Law countries such as those in continental Europe view corporations as "mini-societies", and place emphasis on the responsibility of the firm to its employees as well as its shareholders. Social norms have pushed this view of the corporation to its extreme form in Japan where the responsibility to the interest of employees and other stakeholders such as suppliers outweighs responsibility to the shareholders (see Yoshimori (1995)). In section 3, we argue that the Anglo-American viewpoint goes in hand with a limited liability of shareholders, in case of bankruptcy, that stands at odds 
with the very definition of private ownership: stricto sensu, as long as they have limited liability, shareholders are not the owners of a firm. Furthermore, relying on recent results from general equilibrium theory with default, we suggest that limited liability is responsible for Pareto inefficiency and ethical inequity at equilibrium. We therefore argue that the mainstream understanding of shareholders with limited liability as being the owners of a corporation has no legal ground, nor economic justification.

Clearly, in spite of the wealth of arguments that can be put forward against it, the idea that the corporation should serve the exclusive interest of its shareholders remains the dominant paradigm for corporation governance and for many academic economists. Nevertheless, there are some attempts to expand the focus of the firms' responsibilities to a larger group than its shareholders, including employees and consumers as well as other groups such as suppliers and subcontractors involved in their long-term productive relationship. Magill, Quinzii \& Rochet (2010) offer a promising model of such a "stakeholder corporation". They adopt a Coasian approach to this problem, and suggest that "responsible" firms should issue, together with equity shares, tradable property rights for employees and consumers. In the last section of this paper, we discuss this Coasian approach, as well as the alternative recourse to Pigouvian taxes. We shall show, in particular, that a company's goal should include the concern of all the stakeholders of a company - a goal that cannot be adequately addressed solely by Pigouvian taxes or by property rights. Coming to terms with a broad understanding of the goal of a company should imply the internalization of all the stakeholders' concern within the legal structure of the firm. This third way is illustrated by means of already-existing legal structures, such as the CIC (Community Interest Companies) in the UK or the SCIC (Sociétés Coopératives d'intérêt Collectif) in France.

\section{Why shareholder value maximization is not a legitimate goal}

\subsection{The philosophical roots}

Underpinning the shareholder perspective, from a moral standpoint, the idea is already developed by Mandeville (1714) through his well-known Fable of the bees: "private vices are public benefits". Personal behavior that can be considered morally problematic, or even sinful, can have good social consequences. The luxury and the greed of the rich gives jobs to the poor. In the end, says Mandeville, it is very difficult to separate a good act from an evil act because its moral value depends on the consequences: "It is in morality as it is in nature, there is nothing so perfectly good in creatures that it cannot be hurtful to any one of the society, nor anything so entirely evil, but it 
may prove beneficial to some part or other of the creation: so that things are only good and evil in reference to something else, and according to the light and position they are placed in." (Mandeville (1723)).

\subsubsection{A misinterpretation of Smith's "invisible hand"}

In a way, the famous perspective of the "invisible hand", described a few years later by Adam Smith, seems to express the same idea. Nevertheless, unlike Mandeville, Smith has not pleaded in favor of moral relativism and was conscious of the need to regulate the market and fight against the excesses of profit maximization. The Theory of Moral Sentiments as well as the Wealth of Nations praise the man of public spirit and advocate in favor of taking into account the needs of others in the public sphere, both political and economic. Adam Smith doesn't say that free markets always maximize the society's total utility and that individual self-interest always benefits society. He recognizes the dangers of the commercial spirit: "There are some inconveniences ... arising from a commercial spirit. The first we shall mention is that it confines the views of men. Where the division of labor is brought to perfection, every man has only a simple operation to perform. To this his whole attention is confined, and few ideas pass in his mind but what have an immediate connection with it. ... Another inconvenience attending commerce is that education is greatly neglected. ... Another bad effect of commerce is that it sinks the courage of mankind and tends to extinguish the martial spirit. In all commercial countries the division of labor is infinite, and every ones thoughts are employed on one particular thing. ... In the same manner war comes to be a trade also" (Wealth of Nations, Book V, chapter 3). Smith argues that there are different means by which countermeasures have to be taken, in particular moral incentives and legal rules.

Let us also note, as has been shown by Luigino Bruni and Robert Sugden (2008), that Smith' anthropology was more pessimistic than that of his contemporary Genovesi. According to Smith, we must acknowledge that the economic sphere implies morally negative human relationships. That's why some justice principles have to be implemented in order to prevent the prevalence of injustice. Positive relationships involving "social passions", that is to say, trust, friendship and love, belong to another part of human life. A clear difference is made between market relations and social/interpersonal private relations: the market sphere is ruled according to anonymous and contractual relationships inspired by self-love, whereas the private sphere leaves room for the expression of altruism, compassion and generosity inspired by self-sacrifice. According to Genovesi's Lezioni di comercio (1765), this distinction is debatable. Market relations can and should be based on mutual interest, reciprocity and trust. Bruni and Sugden (2008) have shown how this orientation in terms of mutual assistance allows one to dismiss the radical and irreconcilable opposition between a market where selfish interest prevails and a private sphere where self sacrifice would be the utmost ex- 
pression of love and true care. Seeking mutual assistance means reasoning in common, as "us", and not only as "me" opposed to "you" (market) or as "me" self-sacrificing for "you" (family). Obviously, the debate between shareholder defenders and proponents of the stakeholder viewpoint (to which we shall come back later) can be seen as a late avatar of this former debate: the stakeholder standpoint implies a reasoning as "us".

\subsubsection{Mill's utilitarianism}

This perspective is close to the one proposed by John Stuart Mill. As is well known, Mill's moral views on economics were first deeply influenced by Jeremy Bentham, whose utilitarian approach consisted in looking for "the greatest pleasure for the greatest number" (Bentham, 1789), through the hedonic calculus. Bentham proposed quantifying personal and social utility; after him, economists went even further, by aggregating utility functions of the individuals and comparing them. Utilitarianism seems to favor economic growth through the maximization of the global or the average utility. This leads to two different series of views on economic activity and on public policies: on the one hand, it can justify public policies aimed at increasing global growth even if some people are worse off. On the other hand, it can justify the search for one's private interest as a means to contributing to the global good.

Mill (1863) criticizes both views. First, he shows how personal and social welfare are not attained directly through economic growth and profit maximization. The quality of utility is more important than the quantity of goods that are owned by a person or a group. The most important things, he claims, consist in valuing relational, cultural, intellectual, moral resources and not only material economic growth: "It is better to be a human dissatisfied than a pig satisfied; better to be Socrates dissatisfied than a fool satisfied" (Mill (1863) chap. II). Secondly, this means that the aim of a human being may not consist in looking for his own self-fulfillment in a selfish way. The ideal education orients a person towards the interests of his fellow human beings: "Not only does all strengthening of social ties, and all healthy growth of society, give to each individual a stronger personal interest in practically consulting the welfare of others; it also leads him to identify his feelings more and more with their good, or at least with an even greater degree of practical consideration for it. He comes, as though instinctively, to be conscious of himself as a being who of course pays regard to others." (Mill, 1863, chap. III) This perspective has to be reached through education. All institutions, including private organizations, are supposed to work for the goal of a better world. It is not true, according to Mill, that aggregated, individual self-oriented desires will naturally contribute to the common good; rather, it is possible to educate everyone so that she may find joy in working for the common good. Mill's perspective is in accordance with Genovesi's 
view on market relations as being possibly oriented towards mutual assistance. Nevertheless, Mill goes further as he claims that education can lead individuals to look not only for a mutually beneficial exchange but also to general common interests.

In any case, mainstream economics has forgotten the moral perspective as it was defended by Smith, Genovesi and Mill, and, on the contrary, emphasizes the contribution of personal and selfish interests to global growth, in the line of Mandeville and of the misinterpretation of Smith. The instrumental perspective of ethics justifies some collateral damage. If global welfare is increased it could justify that some economic actors leave the moral perspective aside. The invisible hand, understood as the coordinator of private interests, will make the most of the individual and private quest for profit. That is exactly Milton Friedman's perspective on business and on corporation Social Responsibility: "In a free-enterprise, private-property system, a corporation executive is an employee of the owners of the business. He has direct responsibility to his employers. That responsibility is to conduct the business in accordance with their desires, which generally will be to make as much money as possible while conforming to the basic rules of the society, both those embodied in law and those embodied in ethical custom" (Friedman (1970)).

\subsection{When maximizing profit does not improve welfare}

As alluded to in the Introduction, the misinterpretation of Smith's invisible hand seemed to receive a strong support through the standard theory of general economic equilibrium, as developed in textbooks like Mas-Colell (1985). There, it is proven that, whenever production exhibits decreasing returns to scale, markets are complete, and, in the absence of externalities or public goods, Arrow-Debreu equilibria exist, are generically finite in number, and are all Pareto-optimal. Inexistence of equilibria would make the whole model vacuous; local uniqueness ensures that comparative statics makes sense; Pareto-optimality guarantees that, to some extent, the individual self-oriented behavior of economic agents indirectly contributes to social welfare thanks to the market institution. Firms, in particular, by maximizing their profit not only don't harm their stakeholders but even take part in the collective effort of optimizing social welfare.

This well-known result, however, has been extensively challenged in a number of directions. Firstly, when a firm's activity induces externalities, a competitive equilibrium need not be Pareto-optimal (Arrow (1969)). This means that the market is unable to provide the correct price signals for economic agents to coordinate on a socially optimal outcome. In other words, profit-maximizing may be socially detrimental as soon as a firm's production process induces negative externalities. 


\subsubsection{Externalities, nonconvexities and public bads}

Second, when a firm's production set exhibits increasing returns to scale or more general nonconvexities, profit maximization becomes highly problematic. First of all,

(1) because it might be the case that, for a certain price vector, the firm's optimization programme has no solution at all. Profit maximization then becomes meaningless and needs to be replaced with alternative rules of behavior. Several kinds of such alternatives have been suggested in the literature (marginal cost pricing, loss-free pricing, etc. (cf. Cornet (1988), Giraud (2003a)). The interesting point is that they all require giving up profit maximization as a meaningful rule of thumb for corporations.

(2) Even if one agrees on one of the other non-profit-maximizing alternative behavior for each firm, an equilibrium no longer needs to exist at the level of generality considered in the standard convex case (Salchow (2006)). This means that the choice of an alternative behavior is no longer a matter of individual tastes: Not only profit maximization, but also alternative behaviors, are, in general, not compatible with the emergence of an equilibrium price system. These behaviors should therefore be the subject of a public, democratic discussion.

(3) Even if an equilibrium exists, there is no reason for it to be Paretooptimal (Guesnerie (1975), Dierker (1987)). This makes the case, again, for a public (and democratic) discussion of a corporation's behavior — not only among its shareholders, not even only among its stakeholders, but among all the members of a given society, as they are all affected by the welfare loss possibly induced by each corporation's choice of its own individual behavior.

(4) Finally, given some equilibrium price system, it may be the case that a firm's behavior - be it profit-maximizing or not - induces losses. Such a corporation could not survive in an economy where profit maximization is the unique means of raison d'être for existence. And it might well be the case that closing the firm would further reduce the social welfare of the whole population. In such a case, the public sector should definitely intervene in rescue of this firm.

In the face of such an impressive denial of private profit maximization, one could be tempted to argue that nonconvex production might rather be an exception in modern economies. On the contrary, standard empirical investigation shows that it is rather the rule - and even that it is called to extend to larger areas in as much as climate change is taken into account. Arrow (1969) perceived, indeed, the failure of profit-maximization associated with externalities as a problem of market incompleteness (a viewpoint to which we will return in the next section). He showed that the equivalence between a competitive equilibrium involving profit-maximizing firms and a Pareto optimum can be restored if markets for external effects can be created. However, employing Arrow's framework, where the commodity space is extended to include the rights to generate externalities as additional 
commodities, Starrett (1972) demonstrated that the presence of detrimental production externalities creates fundamental nonconvexities in the technology sets of firms. This fundamental relationship between externalities and nonconvex production is all the more relevant today with the development of a market aimed at internalizing the polluting externalities related to the emissions of greenhouse gases (Funza (2010)). In any case, it suggests, at the very least, that nonconvex production, and its associated disqualification of profit-maximization, are not an exotic exception to be simply put aside.

\subsubsection{Pigouvian taxes often help...}

Given the conclusion of our preceding observations, the question arises about the existence of an alternative mechanism that will, in the presence of externalities, ensure the equivalence between the underlying equilibrium concept and Pareto optimality. When there are externalities, private costs and social costs differ, and competitive equilibria are not likely to be Pareto efficient. Agents will typically make poor social choices, for example, smoking too much or driving too much, because they do not take into account the cost they impose on bystanders who must inhale their smoke or exhaust fumes, not to mention getting crowded out of highway space. Lindahl (1919), Pigou (1920, 1932) and Baumol (1972) famously argued that taxes could be an appropriate antidote to the socially false incentives provided by competitive prices, because if the taxes were set equal to the external cost imposed on third parties, then agents would effectively internalize the externality, taking into account the cost they imposed on others. Pigouvian taxes can be interpreted as a decentralized mechanism where the government is also an economic agent, whose responses (the determination of the Pigouvian taxes on the externality generators and the redistribution of tax revenue) depend on the information (the shadow prices) communicated to it by the agents affected by externalities. As it has been well documented, an equilibrium with Pigouvian taxes is compatible with nonconvex technology sets of the firms facing detrimental externalities, so long as the technologies of these firms are convex in the appropriate subspaces (Hurwicz (1999)).

It is a curious fact that most policy makers regard taxes as bad, while at the same time they recognize the existence of widespread externalities. In this paper we try to make the case that there is almost always a tax package that is good for everybody. Despite general familiarity with Pigouvian taxation, policy makers have not embraced the concept of "good taxes". As emphasized by Geanakoplos \& Polemarchakis (2008), there are at least three reasons.

In the first place, any one tax hurts some people while helping others. The bystander does not have to breathe as much noxious air, but the smoker must pay a tax and not enjoy as many cigarettes. Unless one is prepared to make interpersonal utility comparisons, valuing bystanders' utilities more than smokers' utilities, the Pigouvian observation about divergent private and social costs is not an argument by itself for taxation. 
Second, if Pigouvian taxation is taken to its logical conclusion, then different individuals should face different tax rates for the same good. (A smoker who always lights up outdoors should pay less tax than his brother who only smokes in crowded restaurants, because he causes less damage.) This idea was elaborated in Lindahl (1919, 1928), Samuelson (1954), Coase (1960), and Arrow (1970). At a Lindahl equilibrium, Pareto efficiency is achieved by charging different taxes for the same good, depending on the buyer. Furthermore, combining these individual specific taxes with a carefully chosen program of individually targeted income redistribution (often exceeding the revenue raised by the taxes) can achieve allocations that Pareto dominate purely competitive equilibrium. But such detailed, and discriminatory, interventions seem hopelessly complicated, and possibly illegal.

Third, even if it were practical to implement a plan that taxed commodity purchases and redistributed income on a person specific basis, how would the tax authorities ever know which individuals to charge the higher taxes? As Arrow (1970) pointed out, Lindahl equilibrium does not satisfy the incentive compatibility constraints of Hurwicz (1972), since it is not in the interest of individuals to reveal the information necessary for the price mechanism to function. Thus, the state should construct a revelation mechanism where the adverse selection issue is dealt with, presumably through some rewards granted to people who reveal the truth. This rewards has a social cost which makes it impossible for the state to reach a first-order Pareto optimum. Hence, it seems that only second-order Pareto-optima are within the scope of Pigouvian taxes.

Several answers must be given to these various objections against the use of taxes. First of all, Genakoplos \& Polemarchakis (2008) show that, if the social planner can discover the population distribution of household type, then, most of the difficulties alluded to disappear. Indeed, they show that for almost all externalities, there is a way to make everybody better off than they would be under perfect competition by taxing or subsidizing commodities anonymously (everyone pays the same tax) and redistributing the tax revenue anonymously (each household gets the same rebate, independent of their income or how much they spent or what taxes they paid). It is not necessary to make interpersonal utility comparisons to see that this tax package is better than laissez faire, taxes do not need to be individual specific, and the central planner needs to know about population characteristics and not about individuals.

\subsection{3 ‥ but not always}

The problem, however, is that, even absent of any problem related to adverse selection, while any Pareto optimum can be decentralized as a Pigouvian tax equilibrium, the opposite is not true. Baumol and Bradford (1972) showed that, if the detrimental effects of externalities on victim firms are sufficiently large, the aggregate technology set of the economy could well be nonconvex. 
In such a globally nonconvex economy, although the first order conditions of Pareto optimality would hold at a Pigouvian tax equilibrium determined by government-chosen tax levels, the second-order conditions for even a local Pareto optimum may fail - a standard failure known for marginal-cost pricing rules in nonconvex economies. Thus, an arbitrary Pigouvian tax equilibrium may not be efficient, unless one restricts the class of economies to those where the externalities are weak enough to ensure global convexity, as is done in Hurwicz (1999). More generally, Hurwicz (1999) shows the impossibility of the existence of finite-dimensional decentralized mechanisms that guarantee Pareto optimality in the presence of externalities, for all economic environments (including nonconvex ones).

The fundamentality of nonconvexities for real economies with externalities has been challenged, however, by Boyd and Conley (1997). They argue that nonconvexities are fundamental to the Arrow/Starrett framework because it does not seem to offer a method of placing reasonable bounds on the extent to which the victim firms can observe the externality (sell externality rights to the generators). In real economies, they argue, there are natural limits to the extent to which externalities can be generated. For example, the capacity of land, water, and air to absorb wastes and pollution is really not unlimited. According to them, nonconvexities with externalities are no longer fundamental in a model that treats the externality absorption capacity of the economy as a bounded resource that has different qualitative values for different agents. Thus, they propose a decentralized mechanism in the spirit of Coase (1960) for convex environments, where the endowment of this capacity is bounded and distributed among agents who trade them. They then prove the equivalence between an equilibrium and a Pareto optimum in this setting. If their argument were correct, this would leave open possibility where profit-maximization would, again, be legitimate when supplemented either with a distribution of Coasian property rights or with Pigouvian taxes.

We shall return infra to the debate about Pigou versus Coase. For the time being, let us explain why we firmly disagree with the latter argument. In a sense, Boyd and Conley (1997) rephrase detrimental externalities as the production of a public bad (i.e., a bad of collective consumption), and look at Lindahl equilibria of the corresponding economy. Postulating the scarcity of this public bad, they conclude that a Lindahl equilibrium where agents can trade the public bad are optimal (under otherwise standard conditions). It is clear that, on a human scale, the quantitative resources of, say, fossile energy that can be used on Earth is bounded (given the slowness at which plankton is transformed into fossile reserve). But if we were able to extract the totality of the underground reserves of oil and to burn it, there is little doubt that we would produce a sufficient amount of GHG to make life on Earth impossible. Therefore, the boundedness of the quantity of public bad that our available technology is able to produce does not mean the boundedness of the damages that such a production can cause. In fact, the level of damages explodes to infinity at a finite level of production of public bad. Since the authors 
consider damages that are always finite (given a finite level of produced public bad), their argument, we think, misses the main challenge faced by modern economies.

\subsubsection{Incomplete markets}

These two lines of argument (externalities and, more generally, nonconvexities) would already be enough to discredit shareholder value maximization. Unfortunately for the defenders of this principle, we are not yet at the end of our criticism. Another implicit assumption in the classical welfare theorem is market completeness. Suppose markets are incomplete - and who could claim that markets will, one day, be complete? - , then new troubles arise for profit maximization. (Recall also that, in Arrow's (1969) view, externalities that are not internalized by some $a d$ hoc market can be viewed as a symptom of market incompleteness.) This time,

(i) even the profit-optimization programme in itself may become meaningless as there are various ways to interpret what maximizing profit means in a world of incomplete markets (Drèze (1974), Geanakoplos (1990)). This is due to the fact that the choice of a discount factor and of substitution rates among uncertain states of Nature, ${ }^{1}$ when evaluating the future expected cash-flows generated by a given production plan, can no longer be uniquely deduced from first-order conditions. ${ }^{2}$ Hence, different shareholders adopting different "shadow prices" may envision quite distinct production plans as being "profit-maximizing". Thus, even if all the shareholders agree on the "purpose" of maximizing a firm's revenue, such a purpose can no more be operationalized, in general: There is still room for debate within the shareholders' assembly about what this concretely means - cf. Crès and Tvede (2004). In two famous papers, Drèze (1974) and Grossman \& Hart (1979) have proposed various criteria that could substitute for profit-maximization. None of them is reducible, in general, to profit-maximization as soon as markets are incomplete.

(ii) Moreover, even if, by chance, shareholders were to unanimously agree on what they consider profit-maximizing production plans to be, a competitive equilibrium may robustly fail to exist (Momi (2001)). "Robustly", here, means that existence cannot be restored even by some infinitesimal perturbation of the economy's parameters: there is a whole, non-empty, open subset of these parameters for which the economy fails to admit any equilibrium. In such a situation, one could try to complete markets in order to avoid all these problems and with the hope of being able, this way, to put again the legitimacy of profit maximization on firm grounds. But this is obviously inconsistent: Adding a new security with the aim of reducing market incompleteness creates a new market risk (linked, say, with the uncertain price of

\footnotetext{
${ }^{1}$ These factors are sometimes called "shadow prices".

${ }^{2}$ A problem which is equivalent to the non-uniqueness of the "martingale probabilities" arising from no-arbitrage conditions that are widespread in mathematical finance.
} 
this new security) against which no hedging instrument is available. This is the reason why

(iii) As soon as markets are incomplete, the celebrated local uniqueness of equilibria gives way to a huge indeterminacy of equilibria (Balasko \& Cass (1989) and Geanakoplos \& Mas-Colell (1989)). Not only does comparative statics loose any sense, but this even prompts the question of who will be in charge of helping economic agents coordinate the "right" equilibrium, given that there are infinitely many such candidates, arbitrarily close to each other, and that markets by themselves do not provide the right incentives for agents to elicit one focal equilibrium.

(iv) Last, but not least, even if equilibria exist, they are generically second-best inefficient. This says not only that equilibria may fail to be Pareto-optimal, but much worse: Except for very exceptional situations (which would have no chance of occurring in a world where an economy's characteristics were selected at random) every competitive equilibrium induces an allocation of assets and production plans that are inefficient, even when due account is taken from market incompleteness. In other words, a social planner could always improve the welfare of the society by redistributing initial portfolios of financial assets (Geanakoplos \& Polemarchakis (1986), Drèze et al. (1990)). Of course, we do not claim here that the social planner's intervention itself may not encounter difficulties on its own (essentially related to the cost of extracting privately held information). But at least, we believe that this should convince even the most sceptical that profit-maximizing cannot be considered prima facie as legitimate behavior for firms. Moreover, there are situations of interest where this generic indeterminacy of incomplete market equilibria with profit-maximizing firms lead to involuntary underemployment (Thomas (1995)). In such cases, a fiscal intervention, relying on observable variables only, may Pareto-improve the market-regulated equilibria, and increase the rate of employment (Thomas, loc. cit.).

\subsubsection{Is financial innovation the answer?}

A second reply to our argument maintains that adding new securities, even if it is not enough to restore existence whenever equilibria fail to exist, could at least help reduce their inefficiency when they do exist. After all, is there any other ground for the tremendous growth of financial innovation that we observed over the last three decades? By creating new securities, the financial industry provides our economy with new insurance tools that reduce our risk exposures - so goes the argument. If this were correct, it would mean that the failure of profit-maximizing is not due to the intrinsic inability of profitmaximization on the part of private corporations to cope with the collective interest (whatever this might mean) but rather to the lack of innovation in financial markets. However, even this escape route turns out to be a deadend. As shown by Elul (1995), as long as the newly added security does not 
allow for the completion of markets, financial innovation has an ambiguous effect in terms of welfare: It may indeed increase the welfare level induced by some previous equilibrium, but it may as well give rise to new equilibria that are even more inefficient than the preceding ones! Roughly speaking, this is due to the fact that the reduction of risk exposure of a client through a new security does not mean that the risk has disappeared: it has only been transferred to some other clients with a different attitude towards this specific kind of risk. Hence, the systemic impact of financial innovation may remain ambiguous even though its local impact (focused on the buyer of the new asset) is not.

Moreover, adding new securities is far from meaning that they will be effectively used (hence, that they will effectively help comple markets), even though they promise to reduce their owner's exposure to risk: during the financial crisis of 2007-2011, the enormous amount of credit derivatives that were created during the past decade suddenly collapsed, and nobody wanted to trade these assets anymore. More generally, the presence of collateral requirements is known to endogenously induce incomplete markets because the scarcity of collaterals prevents traders from trading assets that they would otherwise wish to trade (Zame \& Geanakoplos (2002)). Finally, even in the absence of collateral requirements, ambiguity aversion may also prevent economic agents from exploiting the opportunities of complete markets, making them, again, endogenously incomplete (Tallon (2000)).

In conclusion, despite the efforts of the past three decades by the financial industry in order to create new financial assets, the strong inefficiency of competitive equilibria when firms maximize their profit, and even the lack of meaning of profit-maximization within such a framework, are resilient - we must live with. Thus, economic rationality per se requires abandoning profit maximization as the ultimate watchword of a firm's behavior, and to look for alternative behaviors.

Three points must be added to close this section. Firstly, for the sake of brevity, we confined ourselves in the preceding discussion to a perfectly competitive setting (where market agents cannot individually affect prices). Addressing imperfect competition would only strengthen our conclusion (Giraud (2003b)). Second, we also took for granted that efficiency is correctly captured by the concept of Pareto-optimality. This is, of course, a short-cut. Pareto-optimality may be viewed as a necessary condition for efficiency, but it is far from being sufficient. Such a discussion would lead us to cooperative game theory, which goes beyond the scope of this paper. But the main conclusion would be that, even in a perfectly competitive market, even in the absence of externalities, nonconvexities and public goods, even if markets are complete, the "efficiency" of Walras equilibria is disputable (see, e.g., Giraud (2004)). In addition, we can refrain from entering this dispute since, as we just recalled, the minimum minimorum encapsulated in Paretian optimality is not fulfilled by Arrow-Debreu equilibria, as soon as the tiniest dose of realism is added to the basic framework of General equilibrium theory. 
The third point is that, even if, by chance, Arrow-Debreu were efficient (how improbable it is), this would by no means imply that they verify any kind of fairness. Again, this aspect of the debate would lead us too far afield. Let us simply mention that fairness, in the simple form of the leximin criterion, and despite its vehement rejection by certain academic economists until the late 90s, has received a full-blown axiomatic justification in an ordinal setting by Fleurbaye \& Maniquet (2006). Needless to say, the second welfare theorem implies that no fairness property can be obtained, in general, from the self-regulating functioning of decentralized markets populated by profit-maximizing corporations. This is true, even in the idealized case of barter economies with complete markets for purely private goods, convex production, and no externality.

\section{Who is the owner of a corporation?}

So far, we have put forward the idea that profit-maximizing is not beneficial to society, at least in terms of welfare. This is essentially a normative argumentation formulated in terms of a cooperative concept of welfare. There is another line of argument, of more positive and legal nature, that tries to defend the idea that a corporation's end should focus, above all, on the maximization of its dividends. Being the property of its stockholders, a company would be deviating from its objective, so goes the argument, if it did not first orient its activity toward the maximization of return on investment; any action oriented towards non-share-holders should be understood as secondary to this objective. Whether such a profit-oriented activity is welfare-improving, or not, would then be a second-order question when compared to the mere respect of private ownership. This position rests on the idea that private ownership, whatever its consequences, is a priority towards social usefulness. In the US, this position was reinforced by a 1919 court decision (Dodge Brothers vs. Ford Motor Company, 1919: 170 N.W. 668). The issue at stake was the following: is it legitimate for the Ford Motor Company to incur societal expenses if such an action would reduce the stockholders' dividends? The court, whose famous decision comes from a contractualist perspective of the company, ruled in favor of property rights and thus the maximization of profit for the stockholders: "A business organization is organized and carried on primarily for the profit of the stockholders".

From our point of view, this position is nevertheless questionable in several respects.

\subsection{Ownership does not imply profit-maximization}

First of all, even if one were to agree with the thesis that shareholders are the owners of a corporation (more on this later), one could not deduce from this premise that such owners should maximize the profit of their firm. To 
see this point, let us ask: How would the shareholders come to agree on a specific production plan as being profit-maximizing? As already seen, profitmaximization is not a univocal purpose as soon as markets are complete. Thus, whether the general assembly can succeed in agreeing unanimously on a specific production plan is far from obvious. Some bargaining process must occur among shareholders, at the end of which a production plan will be selected.

Does this plan have any chance at being profit-maximizing? Obviously, this is no longer a normative issue, but rather, a positive one. A partial answer has recently been provided by Britz, Herings, and Predtetchinski (2010, 2011). Suppose that all the shareholders take part in a repeated bargaining process à la Rubinstein: every round, one shareholder is selected at random to make a proposal; if it is unanimously accepted, the game is over; otherwise, either one begins a new round of bargaining or (with little probability) no-production is implemented. Then, the only outcome that will be selected (under fairly standard conditions) arises after a single round of negotiation and is the Nash-bargaining solution ${ }^{3}$ weighted by the respective probability with respect to which each shareholder can be selected.

Clearly, the Nash bargaining solution is (second-best) Pareto-optimal, hence, from a normative viewpoint, it should be preferred to the profitmaximizing solutions as soon as markets are incomplete. The most striking point is that, even if markets are complete, the Nash bargaining solution does not coincide with profit-maximization. Of course, this result depends heavily upon the bargaining procedure used: another procedure could possibly lead to another non-cooperative outcome. Nevertheless, the standpoint adopted in Britz, Herings, and Predtetchinski (2011) provides a strong case against profit-maximization: Whatever the asset market structure is, rational shareholders, even if considered as the "true" owners of the firm, should not, in general, choose to maximize its profit if they are to bargain according to Rubinstein's rules.

\subsection{Ownership implies full liability}

In addition to this first counterargument, the second we would like to record against profit maximization (understood as the mere manifestation of private ownership of the company) is the following: private ownership means a right to own future profits and losses. This stands in sharp contrast with the limited liability of shareholders. Bankruptcy law plays a central role in modern economies, determining access to credit and allocation of assets. Yet, both the bankruptcy law and its enforcement vary widely across developed and developing countries, between industrialized countries, and between different states within a given country. For example, personal bankruptcy law is far less lenient in Germany than in the US. Under German law, defaulting borrowers have to pay a significant portion of their earnings for six years after

\footnotetext{
${ }^{3}$ Cf. Giraud (2009) for an introduction.
} 
the default, while Chapter 7 provisions in the US have traditionally allowed most borrowers to not incur any liability against future earnings after a default. The liability of borrowers under Chapter 7 at the time of default is limited to assets owned at that point of time, in excess of an exemption limit. Those with fewer assets than the exemption limit do not incur any liability at all. These exemption limits vary widely across different states in the US (Gropp, Scholz and White (1997)). It is useful to recall that, in certain times and places, extra-economic consequences of defaulting as drastic as hanging (12th-Century France) or exile to the colonies (18th-Century England) have played an important role. Debtors' prisons were in widespread use in Western societies well into the middle of the 19th Century — see Dubey, Geanakoplos and Shubik $(1990,2005)$ for a general treatment of extra-economic penalties and Sabarwal (1999) for a general equilibrium treatment of exclusion.

Now, if the effective owners of a corporation are those who effectively bear the responsibility of a company's debt - namely the state when, say, the company is "too big to fail" - , then this means, we hold, that the state is the effective owner of such corporations whose default would induce a systemic risk - not their shareholders. The specific case of companies that entail a systemic risk shows, at least, that It is worth thinking a bit more closely about the legal dispositions regarding the liability of shareholders. Does one of them emerge with regard to its efficiency properties in modern markets? Does this "ideal" disposition imply full liability? Could one base a plea in favor of profit-maximization on such a legal disposition?

Full liability was actually the implicit assumption of Friedman (1953) when he claimed that, in the long-run, markets are efficient. His argument can be restated as follows within a general equilibrium setting (see Blume and Easley (2006) and Cao (2010)). Suppose that market traders have different beliefs about tomorrow's uncertainty. The difference in beliefs induces them to take large bets under frictionless complete financial markets, which enable agents to leverage their future wealth. Consequently, as hypothesized by Friedman (1953), under complete markets, agents with incorrect beliefs will eventually be driven out of the markets. In this case, they also have no influence on asset prices and real investment in the long run, so that, in the long-run, only agents with correct beliefs survive. This argument holds only if, when defaulting on his promises, an agent loses so much wealth that he is effectively driven out of the market. Thus, when Friedman - the defender of profit maximization as a corporation's unique goal-claimed that markets are efficient, he relied, at least implicitly, on a strong understanding of private ownership as associated to unlimited liability and to some form of implicit social darwinism: those with incorrect beliefs should, and will, be "eliminated" from the market.

In contrast, Cao (2010) shows that under potentially incomplete markets generated by collateral constraints, agents with heterogeneous (potentially incorrect) beliefs survive in the long run, so that their speculative activities continuously drive up asset price volatility and real investment volatility. 
This not only means that Friedman's claim of markets' efficiency loses its ground once again, it means above all that an efficient definition of ownership should include unlimited liability. This is obviously not so, at least for certain market actors who have only limited commitment, as illustrated by the story of the founder of Long Term Capital Management. ${ }^{4}$ Within this perspective, we face a dilemma. Either shareholders with limited liability are considered as the proper owners of a corporation - but then, Friedman's implicit social darwinism fails, so that, again, profit-maximization loses its welfare justification - or, shareholders with limited liability are not the proper owners of a corporation, in which case, they have no right to impose profitmaximization as the sole objective of a firm.

\subsection{Should the State control a corporation?}

In this second case, if the State is one the effective owner of a corporation (e.g.,of the Banks and insurance companies that are "too big to fail"), it should at least be able to exert a control on the firm - a control that incorporations the search for the common good (whatever its definition) within the objectives of a firm. In any case, this control is very hard to put in place, at least in the US.

In the U.S., corporations were initially defined by revocable charters, which were enacted by each state. Then, after some years, corporations were directly acknowledged as moral individuals having rights but with fewer related obligations. The 1886 text that recognizes the moral character of corporations (corporation personhood) in fact gives corporations the same rights as individual persons but not the same duties. As a result, stockholders don't have real responsibility for political control of the company and cannot be sued. Consequently, corporations were able to dictate their own conditions, if not influence or dictate the regulations that concern them, whereas federated states were placed in a position of competition where they offer these corporations more advantageous fiscal conditions and less strict regulations in order to attract investments. Little by little, associations were formed (trusts, fusions, holdings), which allowed for financial concentrations to reinforce the power of large corporations. Similarly, at the beginning of the 20th century, the characteristic phenomena associated with American capitalism came about: that of cross-participation, including in administration coun-

\footnotetext{
${ }^{4}$ John Meriwether worked as a bond trader at Salomon Brothers. There, Meriwether became the head of the domestic fixed income arbitrage group in the early 80 s and vicechairman of the company in 1988. In 1991, after Salomon was caught in a Treasury securities trading scandal, Meriwether decided to leave the company and founded the Long-Term Capital Management hedge fund in Greenwich, Connecticut, in 1994. LTCM collapsed in 1998. A year after, Meriwether founded JWM Partners LLC. The Greenwich, Connecticut hedge fund opened with $\$ 250$ million under management in 1999 and by 2007 had approximately $\$ 3$ billion. The financial crisis of 2007-2009 badly battered Meriwether's firm. From September 2007 to February 2009, his main fund lost 44 \%. On July 8, 2009, Meriwether closed the fund.
} 
cils. Jouvenel (1933) describes this as the "senatorial class of capitalism", and Rivero (2001) describes it as "the new global aristocracy". Of course, the federal state was not inactive regarding these intrigues and organized the

fight against monopolies through anti-trust laws. The issue of relationships between the state and corporations consists of evaluating the capacity for control (Sherman Act of 1890, etc.) but, in fact, the legal status of corporations and their recognition as moral persons was accompanied, in the United States, by a weakening of state corporation charters and less state control. corporation governance founded on stockholders and the responsibility of stockholders emphasizes the protection of the value of stocks rather than on the corporation assets. However, the conception of the corporation as a moral person opens the possibility of legal recognition of their responsibility as moral actors.

Recent attempts to increase control and provide a framework for corporations have been made: the Sarbanes-Oaxley law of 2002 aims in a very precise and repressive manner to prevent scandals such as Enron or Worldcom, and to allow for more frequent lawsuits against stockholders. The heads of corporations become, moreover, responsible for their goods and the accounts that they approve of by signing off on them. Listed corporations must establish an independent ethical committee composed of members with no special interest ties to the company and who cannot receive financing (beyond the reasonable sums they are paid to be present). However, the Sarbanes-Oaxley laws haven't clarified the distinction between the auditing and consulting professions, which increases the risks of inter-relational risk that is conducive to financial delinquency. Directors of corporations that were guilty of financial offences were recently subject to very severe criminal sanctions that constitute an irruption of financial criminality in American criminal law, whereas, until the 1980s, civil procedures and amicable agreements were used to resolve problems. New laws regarding corporation transparency are envisaged: for example, in 2001, the proposition was made - and then not ratified by Congress - for a corporation Code of Conduct Act that would require corporations to publish reports on their social and societal commitments. Accountancy regulations were tightened, notably by the IAS 37, which required corporations to take environmental risks into account. In addition, regarding environmental manners, several recent complaints reinforced the control of civil society, such as those filed by cities and states of the intrigues of the federal Agencies and large private corporations in matters of respecting the environment and the fight against global warming.

\section{From corporations to companies}

Imagine, now, a situation where the State ensures that it will not intervene in case of bankruptcy, and suppose that shareholders have full liability. Does this make them owners of the company itself? We now argue that the com- 
pany has an existence independent of its stockholders, at the intersection of not only of the shareholders' contradictory interests but also of the employees and the stakeholders. A distinction can be made between the corporation and the company: the stockholders possess their individual parts of the corporation, but even if they have full liability, they are not owners of the company in which they invest. The created economic and social value owes as much to those who hold the capital as to the employees and the different groups concerned by the company's activity.

\subsection{A company is not a corporation}

In Western countries, the confusion between corporations and companies arises because of the lack of a legal definition of the corporation: corporations have been developed in the historical context of liberal theories sensitive to the social contract between individuals within the State and to the market as combining private interests in order to favor economic growth. Corporate law has enlarged the notion of moral personhood to the companies which grant a limited liability to the stockholders, whose goods are separated from the company. The stockholders own shares but are not owners of the assets, which are owned by the company. Thus the top managers (CEO, managing director, etc.) are in a very ambiguous position: they are supposed to monitor and manage the assets of the company and yet, at the same time, they are nominated by the stockholders and are called to be accountable to them. As J.-P. Robé stresses it, "the corporations live through commercial companies which don't personify them but which enable them to exist" ("les entreprises vivent par l'intermédiaire de sociétés commerciales qui ne les personnifient pas mais leur permettent d'exister"). They benefit from the rights granted to individuals while taking advantage of the laws of the different States to optimize their geographical location and their taxation. Taking seriously the idea that, in most cases, the State is the effective owner of a corporation and that the corporation is only a part of the corresponding company would ask to acknowledge a new legal entity — the company-, whose owners would be the various stakeholders of a firm and the State.

This, eventually brings us to the flourishing stakeholder theories. Many of the researchers who want to promote Corporate Social Responsibility have analyzed the relationship between CSR and profit maximization. There is no clear, direct relationship between the two (Margolis and Walsh, 2001, 2003). Nevertheless, it is not unusual to favor an instrumental view of CSR and of business ethics: CSR will increase the ability of a firm to be sustainable; this perspective is expressed through the stakeholder theory (Freeman, 1984, 1999) and the resource-based view of the firm (Hart, 1995; Russo and Fouts, 1997). The stakeholder theory defends the idea that the company has to take into account its different stakeholders, and not only its shareholders. Building bonds of solidarity and confidence is a competitive asset for the company. The resource-based view of the firm focuses on intangibles (innovation, hu- 
man resources, reputation, organisational culture) as a source of competitive advantage. There is a symmetric strand that insists on profit maximization as the means by which a company can be socially responsible, as the sine qua non condition for implementing social programmes. Some scholars, like Sandra Waddock, defend two ideas: first, the relationship goes in both ways (Waddock and Graves, 1997); there is a virtuous circle between corporation Responsibility Performance (CRP) and corporation financial performance (CFP). Secondly, more recently, Waddock and other researchers (Surrocka, Tribo and Waddock, 2009) have shown that the intangibles (reputation, human resources, culture and innovation) seem to be the missing link between CRP and CFP: putting an emphasis on innovation, human resources, corporation culture and reputation increases both CRP and CFP.

Could these perspectives on CSR be considered as the implementation of "fraternity" in market relations, in accordance with the above mentioned analysis of Genovesi by Bruni and Sugden? At first sight, there is a convergence: defending market relations as being legitimately open to mutual assistance. Nevertheless, the caveat mentioned by Bruni and Sugden (2008, p.52) remains: in the case of very asymmetrical relationships, market relations may just express opportunist behaviors. CRP may just be a tool in order to maximize profit for one of the parties, namely the most powerful. Moreover, the literature on CSR often expresses the idea that it is in the long-term interest of the corporations to behave in a more socially responsible way by paying attention to their different stakeholders. Is it enough to defend an enlightened self-interest from the business actors? This approach is typical of the win/win strategy that usually underpins the discourse in favor of CSR. There has to be a business case for CSR: ethics pays. It is all the more important in Anglo-Saxon countries that jurisprudence has insisted on the fiduciary duty of the firm, that it has to be accountable to its shareholders. But, from our point of view, this approach is not satisfying, neither from a business/financial perspective nor from a moral one: empirical studies show that companies that were supposed to be more socially responsible may not have been as well appreciated on the stock markets as other companies that were less careful in terms of CSR (Vogel, 2006). And companies that had a good reputation in one area may have been the center of financial scandals (for example, Enron). Moreover, the ethical perspective stressed by Mandeville and by mainstream utilitarianism is debatable, as we have seen earlier. A firm whose activity implies direct and indirect consequences on its natural and human environment cannot get rid of the problem by claiming that it pays taxes to the government. It has to assess the different impacts related to its activity and acknowledge that there may be conflicting logics and an unequal balance of powers; very often, local communities have been impacted by the extractive industries without receiving adequate compensation. Finally, the search for profit maximization can lead to predatory, greedy behaviors that are still unpunished because they may not be illegal - they play with the "grey areas" of international finance. For example, 
many decisions made by multinational corporations through transfer pricing are legal optimization strategies that are harmful for many developing as well as industrialized countries (Renouard, 2007).

\subsection{Taxes, again, do not suffice}

There are at least three ways to take into account the well-being and the rights of the stakeholders: 1) traditionally the State - through the taxes paid by companies - is supposed to redistribute wealth among citizens, to give access to public services for all and to mitigate environmental damages. 2) The market can also play a role in defining property rights for the stakeholders such as consumers, clients and employees and by internalizing externalities: employees and consumers are given tradable property rights according to the surplus generated by the company (Coase, 1960). 3) Finally, one can ask for internalization within larger entities (by integration of all the parties involved in the externality) of the externalities created by a firm.

We would like to conclude this paper by defending the idea that, in many situations of interest, none of the first two "solutions" is satisfactory. Therefore, only the third one remains, which asks for a reform of the legal definition of a corporation.

Firstly, there are many situations where the State obviously does not play the role that the first solution attributes to it. In such cases, is it morally acceptable that a firm operates in such a country without bearing the responsibility of its negative externalities simply by arguing that the State has ailed? We maintain that, whenever the State turns out to be incapable of sustaining the Pigouvian process of internalizing externalities, this does not mean that a corporation is freed from any responsibility, and can reduce its scope to profit-maximization. Quite on the contrary, it means that solution 1 has to be abandoned, and that one should search for solutions 2 or 3 .

Let us take the example of the extractive industry in the Niger Delta (Renouard (2010) and Giraud and Renouard (2010)). In 2010, the Nigerian production of oil was around 2.3 million barrels per day and oil represented $80 \%$ of the country's GDP and $95 \%$ of its external revenues. Despite the influx of revenue for several decades, there is still widespread poverty on one hand, and a wealthy and corrupt elite on the other, which maintains and deepens inequalities. Income inequality is observed at a national level in any sector. The official salary of a Nigerian member of parliament is $\$ 6500$ per month (about one million Naira). Some observers (among whom Sagay (2010)) claim that Members of Parliaments (MPs) could have granted themselves around $\$ 100,000$ per month (15 million Naira), i.e. more than 820 times the minimum wage of an employee (\$120 per month / 18000 Naira). The Nigerian lawyer Itse Sagay (2010) shows the cruelty of the system by attempting a comparison with developed countries: while the per capita income of the United States, UK and Nigeria respectively are $\$ 46,350 ; \$ 35,468$ 
and $\$ 2,249$, the annual salaries of MPs in these countries are respectively about $\$ 174,000, \$ 64,000$ and $\$ 1.7$ million. In 2009 , the compensation of parliamentarians in Nigeria amounted to some 103 billion Naira, representing up to $5 \%$ of the federal budget. Furthermore, in the oil sector in Nigeria, wages are extremely high: a young expatriate engineer on a production site, working in four quarters (four weeks in Nigeria / four weeks of vacation in his home country) would earn around $\$ 40,000$ per month. The lack of redistribution and of public spending on development by the Nigerian government characterizes the country as a failed State.

\subsection{Does the Coasian "solution" work?}

Magill, Quinzii \& Rochet (2010) have developed a formal model of the Coasian "solution" in terms of tradable property rights. It is formulated within a rewriting of the standard Arrow-Debreu model of production with uncertainty (see Magill and Quinzii (2008)), where states of nature are not independent of the chosen production plans. Rather, the production of a firm influences the probability with which a given state of nature will occur tomorrow. Our purpose, here, is not to discuss this rewriting which, after all, consists in focusing on a sub-case of the more general Arrow-Debreu formulation. If the Coasian approach of the stakeholder theory is convincing within this specific set-up, this should provide us with a good starting point for the more general viewpoint. But our perspective is that, even within the probability model of a firm introduced by Magill and Quinzzi (2008), tradable property rights do not provide a convincing way of internalizing externalities in many situations of interest.

In the probability model of Magill and Quinzii (2008), if the firm uses the shareholder criterion of maximizing the present value of profit, there is always underinvestment relative to the social optimum. Some economists might argue that it would be simpler and surer to model the economy using the Arrow-Debreu equilibrium: this is not the case. Indeed, Magill et al. (2010) show that the economy has no Arrow-Debreu equilibrium. Now, if, in the probability model with homogeneous workers, the firm adopts a stakeholder criterion consisting of profit plus the consumer surplus and the worker surplus then it is led to the socially optimal level of investment. Thus adopting the stakeholder criterion instead of the profit criterion induces the firm to invest more and solves the externality problem.

A stakeholder firm is a hybrid of a capitalist firm, a cooperative of consumers and a labor-managed firm. As such, it inherits some of the well-known drawbacks of the latter two types of firms. In particular these firms are not "entry free" for consumers and employees. Potential workers and consumers of a stakeholder firm have to pay a fixed fee in order to become members of the "clubs" of "authorized" workers and consumers. Therefore some workers and consumers with low surpluses are, in general, excluded from these clubs. Moreover the surplus of inframarginal members of these clubs is only 
partially accounted in the firm value. Indeed this firm value only takes into account the surplus of the marginal worker or con- sumer, which means that it is underestimated. Thus, the only case where the stakeholder form of corporation fully internalizes externalities is when consumers and workers are homogeneous. However, Magill et al. (2010) show that reforming capitalism by shifting even marginally the responsibility of the firm from just the interests of the shareholders to the combined interests of workers-consumersshareholders always leads to an increase in welfare. Indeed the model can be parametrized by the number of property rights issued to consumers and employees. The "capitalist" equilibrium corresponds to the case where there is no scarcity of rights and all consumers and employees can become "members" at no cost. Then the value of the property rights is zero and the total value of the firm is its shareholder value. A marginal change to this system whereby the number of property rights is reduced and the payment of small fixed fee is required to belong to the "club" of the employees and consumers of the firm always increases welfare. The welfare loss associated with the exclusion of some potential employees and consumers is more than compensated for by the increase in investment generated by the internalization of some fraction of consumer and employee's surplus. In this model, "pure" capitalism corresponds to a local minimum of social welfare.

Nevertheless, we argue that, as modest it is, this plea in favor of a Coasian approach to the stakeholder theory of the firm misses one crucial point. If the market is in charge of the allocation of some of the stakeholders' rights, it may not allow many legitimate stakeholders to be taken into account. Let's once again take the example of local communities impacted by extractive industries in the Niger Delta. Most people won't be given the chance to get access to property rights, first of all, because the companies can claim that they are not direct stakeholders. Moreover, and most importantly, most of the time local communities don't have the resources (income, ability to negotiate, access to information, etc.) needed to deal with property rights. Most members of the local communities live below the poverty line, with less than 2 dollars per day; many of them don't speak English. Finally, the interests of the different stakeholders are not necessarily convergent; they may even by contradictory. For example, the level of wages paid to the employees may be disconnected with the average level of wages paid in the area: in Nigeria the minimal wage for a civil servant is around 90 euros per month and a qualified technician of an oil company is paid several thousand euros a month.

In other words, the Coasian "market solution" reproduces the implicit darwinism of markets that, as we have seen, already underlies Friedman's argumentation in favor of a narrow understanding of the firm's objective: it "eliminates" part of the people who are directly concerned by a company's activity. As long as a welfare criterion such as the sum of individuals' utilities is adopted, the elimination of poor stakeholders may be compensated by the average increase in welfare. If, by contrast, the leximin criterion (cf. 
Fleurbaey \& Maniquet (2006)) is adopted, then stakeholders are perfectly complementary, and no such compensation is acceptable.

\subsection{For a legal recognition of the company}

Taking into account the stakeholders - the third way- consists in making sure, by legal requirements, that the company will pay attention to the different interests of its stakeholders. This is a way of extending the legal recognition of corporations to the larger entity represented by the company.

This perspective was indeed defended by Berle and Means $(1932,1991)$ : "Neither the claims of ownership nor those of control can stand against the paramount interests of the community... the passive property right (i.e diffused ownership)... must yield before the largest interests of the society. It is conceivable - indeed it seems almost essential if the corporation system is to survive that the control of the great corporation should develop into a purely neutral technocracy, balancing a variety of claims by various groups in the community and assigning to each a proportion of the income stream on the basis of the public policy rather than private cupidity. " This means integrating in the law the social purpose of the company and making room for the dialog between the top management and all the stakeholders: employees, subcontractors, suppliers, clients, consumers, local communities, and shareholders. Concerning the juridical definition of the firm and its purpose, the proposal made by Hurstel (2009) consists in modifying the French Civil Code (art 1832) and stating that the aim of the company is either to share among the associates the profit related to its economic activity (which is the current definition) or to develop an activity which is an answer to a social need. This allows to formalize the social purpose of a firm as its legitimate goal and to make sure that the top managers who care for the social interests of their stakeholders won't be sued by shareholders. For the time being, different legal forms of companies have been defined in Europe during these past years, in order to develop social entrepreneurship: in England the CIC (Community Interest Companies) since 2004, in France the SCIC (Société cooperative d'intérêt collectif) since 2001. The SCIC is a renewed version of the cooperative system.

The SCIC governance is open to 5 different categories of stakeholders: employees, consumers who benefit from the service provided by the cooperative, volunteers, government (collectivités publiques) and "any physical or moral person that contributes to the activity of the cooperative". The employees and the consumers have to be represented among the associates of the firm. To take a decision, instead of applying the "one man one vote principle", the idea is to constitute bodies (collèges), each of them representing one category of stakeholders. Due to their legal complexity, the SCIC are not very numerous: only 134 were registered in March 2009 (Hurstel, 2009, p.84). Nevertheless they pave the way for the integration of the stakeholders' interests within the organization of the firm. The English CICs created by 
the 2004 Companies Act are more successful: 2,500 were registered in February 2009 (Hurstel, 2009, p.135). They have to develop an activity aimed at providing a service for a given community and they are under the supervision of the Regulator, appointed by the Secretary of State. They are either limited by guarantee (no dividends can be distributed) or limited by share (dividends may be distributed). The "asset lock" principle ensures that the interest of the community will be protected and that the investors and other stakeholders will get a limited, reasonable, return on investment. Between 2005 and April 2011, the maximum share dividend cap was "5 percentage points higher than the Bank of England's base lending rate of the paid value of share". (Hurstel, private communication.) Since April 2010 it is "20 percent of the paid-up value of a share in a relevant company". Even in the US, the State of California has recently defined "flexible purpose corporations" (corporation Flexibility Act, Senate Bill 201, 2011) to react against the overimportance of shareholder value

Is social entrepreneurship a way of transforming traditional capitalist firms? From this perspective, social businesses created by M. Yunus and the Grameen Bank in partnership with multinational corporations (e.g., Danone, Veolia) are good examples of innovative actions: Grameen Danone Foods and Grameen Veolia Water in Bangladesh try to address the needs of poor people by providing yogurt with micronutrients and drinkable water in rural areas (Yunus, 2010). According to Yunus, the common components of social businesses are the following: the social goal, the long term profitability ("no loss") which distinguishes them from philanthropic projects, the very low or zero return on investment for shareholders (Yunus argues in favor of "no dividend" policies), and the ability to pay taxes (Yunus, 2010, p. 123).

\section{References}

[1] Arrow, K.J., (1951) "An extension of the basic theorems of classical welfare economics", In: Neyman, J. (Ed.), Second Berkeley Symposium on Mathematical Statistics and Probability, pp. 507532.

[2] Arrow, K.J. (1969), "Issues Pertinent to the Choice of Market Versus Non-Market Allocations," The Analysis and Evaluation of Public Expenditures: The P.P.B. System, Joint Committee of the Congress of the United States, Washington, D.C. : 47-64.

[3] Arrow, K.J., Debreu, G. (1954) "Existence of an equilibrium for a competitive economy", Econometrica 22, 265290.

[4] Balasko Y. and D. Cass (1989), "The structure of financial equilibrium with exogenous yields: the case of incomplete markets", Econometrica, 57 pp. $135-162$. 
[5] Baumol, W.J. (1972), "On Taxation and the Control of Externalities", The American Economic Review, 62: 307322.

[6] Bentham, J. (1789). An introduction to the principles of morals and legislation. Dover publ. Inc 2007, New-York.

[7] Bonnisseau, J.-M. \& B. Cornet (1990) "Existence of marginal cost pricing equilibria in an economy with several nonconvex firms" Econometrica, 58, 661-682.

[8] Boyd III, J. H., and J. P. Conley (1997), "Fundamental Nonconvexities in Arrovian Markets and the Coasian Solution to the Problem of Externalities," Journal of Economic Theory, 72: 388407.

[9] Bradford, D. F. [2005], "Improving on Kyoto: Greenhouse Gas Control as the Purchase of a Global Public Good," David F. Bradford Memorial Conference on "The Design of Climate Change Policy," Venice International University and CESifo.

[10] Bruni, L. and R. Sugden (2008) "Fraternity: why the market need not be a morally free zone" Economics and Philosophy 24: 35-64.

[11] Britz, V., P.J.J. Herings, and A. Predtetchinski (2010), "Noncooperative Support for the Asymmetric Nash Bargaining Solution," Journal of Economic Theory, 145, 1951-1967.

[12] (2011) "Theory of the Firm: Bargaining and Competitive Equilibrium", Meteor working paper, RM/10/057.

[13] Citanna, A., Kajii, A., Villanacci, A., (1998) "Constrained suboptimality in incomplete markets: a general approach and two applications", Economic Theory 11, 495522.

[14] Coase, R. (1960), "The Problem of Social Cost," Journal of Law and Economics, 3: 144.

[15] Cornet, B. (19880) 'General Equilibrium Theory with increasing returns: Presentation" Journal of Mathematical Economics 17 (1988) 103-118.

[16] Dierker, E. (1987) "Increasing returns, efficiency, and the distribution of wealth", European Economic Review, 3, 1,475-482.

[17] Drèze, J. (1974) "Investment under private ownership: optimality, equilibrium and sta- bility" in Allocation under uncertainty: equilibrium and optimality, ed. by J. Drèze, New York, NY: Wiley.

[18] Freeman, R. E. (1984) Strategic management: A stakeholder approach. Boston: Pitman. 
[19] (1999) "Value maximization, stakeholder theory, and the corporation objective function" Business Ethics Quarterly 12: 235-256.

[20] Friedman, M. (1970) "The social responsibility of business is to increase its profits", New York Times, September 13: 122-126.

[21] Geanakoplos, J., Magill, M., Quinzii, M. and Drèze (1990) "Generic inefficiency of stock market equilibrium when markets are incomplete", Journal of Mathematical Economics, Vol. 19, 113-152.

[22] Geanakoplos J. and A. Mas-Colell (1989), "Real indeterminacy with financial assets", Journal of Economic Theory, 47, pp.22-38.

[23] Geanakoplos, J. \& H. Polemarchakis (2008) "Pareto improving taxes", Journal of Mathematical Economics, 44 (2008) 682696.

[24] Giraud, G. (2003a) "An Algebraic Index Theorem for Non-smooth Economies" Journal of Mathematical Economics, vol. 36, Issue 4, p. 255-269.

[25] - (2003b) "Strategic Market Games: an Introduction", Journal of Mathematical Economics, vol. 39, Issues 5-6, p. 355-375."

[26] — (2004) "Valeur de Shapley et inefficience des marchés concurrentiels" Economie et sociétés 35, 8-9/2004, p. 1599-1623.

[27] - (2009) La Théorie des jeux, Flammarion, coll. Champs, 3rd ed.

[28] Giraud, G. \& C. Renouard (2010) "Mesurer la contribution des entreprises au développement local : le cas des pétroliers au Nigéria", Revue Française de Gestion, vol. 36, 208-209, p. 101-115.

[29] Grossman, S.J. and Hart, O. (1979) "A theory of competitive equilibrium in stock market economies", Econometrica, Vol. 47, 293-330.

[30] Guesnerie, R. (1975), "Pareto Optimality in Nonconvex Economies," Econometrica, 43: 129.

[31] Guesnerie, R. (2005), "The Design of Post-Kyoto Climate Schemes: An Introductory Analytical Assessment," David F. Bradford Memorial Conference on "The Design of Climate Change Policy," Venice International University and CESifo.

[32] Jouvenel, B. de (1933) La Crise du capitalisme américain, Paris, Gallimard.

[33] Mandeville, B. (1714) The Fable of the Bees. Private Vices, Public Benefits.Hackett Publishing, Indianapolis, 1997 
[34] Mandeville, B. (1723) A Search into the Nature of Society.in The Fable of the Bees and other writings.Hackett Publishing, Indianapolis, 1997

[35] Margolis, J. D., and J.D. Walsh. 2001 People and profits? The search for a link between a company's social and financial performance Mahwah, NJ: Lawrence Erlbaum Associates Publishers.

[36] (2003) "Misery loves companies: Rethinking social initiatives by business" Administrative Science Quarterly 48(2): 268-305.

[37] Mill, J.S. (1863) UtilitarianismLondon: Longmans, Green, Reader, and Dyer, 1871, Hackett Publishing, Indianapolis, 2001.

[38] Momi, T. (2001) "Non-existence of equilibrium in an incomplete stock market economy", Journal of Mathematical Economics, Vol. 35, 41-70.

[39] Nash, J. (1950) "The Bargaining Problem", Econometrica, 18 (2): 155162.

[40] Renouard, C. (2007) La Responsabilité éthique des multinationales, Presses Universitaires de France, Paris.

[41] Rivero, O. de (2001) El Mito del Desarrollo, Fondo de Cultura Económica, México.

[42] Salchow, H.J. (2006) "An essay on the state of economic science", Journal of Mathematical Economics, 42, 6, 653-660.

[43] Sagay I., (2010) "Our lawmakers are selfish" (http://234next.com/csp/cms/sites/Next/News/Metro/Politics/5599745147/our_lawmakers_are_selfish_says_sagay.csp), July 2010.

[44] Smith, A. (1976) [1776] An Enquiry into the Nature and Causes of the Wealth of Nations, Clarendon Press.

[45] (1976) [1759] The Theory of Moral Sentiments, Clarendon Press.

[46] Surrocka, J., J. Tribo and S. Waddock (2009) "Performance responsibility and financial performance: the role of intangible resources" Strategic Management Journal 31: 463-490.

[47] Starrett, D. (1972), "Fundamental Nonconvexities in the Theory of Externalities," Journal of Economic Theory 4: 180199.

[48] Thomas, C. P. (1995) "The Role of Fiscal Policy in an Incomplete Markets Framework", Review of Economic Studies, Vol. 62, No. 3, pp. 449468. 
[49] Vogel, D. (2006) "The Market for Virtue. The Potential and Limits of corporation Social Responsibility" Washington DC, The Brookings Institution.

[50] Waddock, S. and SB. Graves (1997) "The corporation social performance-financial performance link" Strategic Management Journal, 18 (4): 303-319.

[51] Walzer, M. (1983) Spheres of Justice. A defense of pluralism and equality. Basic Books.

[52] (1994) Thick and thin. Moral argument at home and abroad, University of Notre Dame Press. 
ESSEC Business School Avenue Bernard Hirsch BP 50105

95021 Cergy-Pontoise Cedex France

Tél. + $33(0) 134433000$

Fax $+33(0) 134433001$

www.essec.fr

ESSEC Executive Education

CNIT BP 230

92053 Paris-La Défense

France

Tél. +33(0)146924900

Fax +33(0)1 46924990

http:l/formation.essec.fr

ESSEC Business School

Singapore Campus

100 Victoria Street

National Library Building \# 13-02

Singapore 188064

essecasia@essec.fr

Tél. +65 68849780

Fax +6568849781

www.essec.edu

\section{Informations}

Hanane Rahmoune +33 (0)134433358

rahmoune@essec.edu

www.essec.fr

research.center@essec.fr

ISSN 1291-9616 